\title{
Unknown Clark Level
}

National Cancer Institute

\section{Source}

National Cancer Institute. Unknown Clark Level. NCI Thesaurus. Code C160701.

A finding of an unknown Clark level. 